p-ISSN: $2338-4794$

e-ISSN: 2579-7476

Vol.7. No. 3 September-Desember 2019

\title{
PENGARUH KEPATUHAN SATKER PADA INDIKATOR KINERJA PELAKSANAAN ANGGARAN (IKPA) TERHADAP PENYALURAN DUKUNGAN ANGGARAN BINOPSLAT
}

\author{
Lesmana Chandra Buana ${ }^{1}$ ) \\ 1) Perwira Mahasiswa Pendidikan Regular Angkatan ke-57 \\ Sekolah Staf dan Komando Angkatan Jakarta Selatan \\ E-mail: lesmana_chandra@tnial.mil.id \\ Nanang Widiatmoko ${ }^{2}$ ) \\ 2) Dosen Sekolah Staf dan Komando Angkatan Laut Jakarta Selatan \\ E-mail: nanang41@yahoo.com
}

\begin{abstract}
Operational Control and Training Activity (Binoplast) activities need support that are effective, efficient, accountable and transparent so that the implementation of operational control and training activity work as plan. IKPA is needed as a monitoring tool and the evaluation to measure the quality of the financial implementation to encourage behavior change of management of financial state. IKPA is an indicator to measure the quality of budget implementation's performance from the compatibility of planning, the effectiveness of activities implementation, the efficiency of activity implementation and the obedient to regulations. The purpose of this research is to analyze the effect of the obedient of units to IKPA in accordance with the distribution of Binoplast's budget support. This research is using mix method and test of instruments research, test of the classic, test of linear and partial and simultaneous, while for qualitative data use the triangulation of interviews. This research will get the result: (1) The obedient of regulations have a strong correlation with the financial management. (2)The effectiveness of the implementation have a strong correlation with the financial management, (3) The efficiency of the implementation have a strong correlation with the financial management (4) The compatibility between planning and implementing the activity have a strong correlation with the financial management. Based on the result, it can be concluded by following IKPA's indicators it can support the distribution of support Binoplast.
\end{abstract}

Keywords: Obedient, performance indicator executive budget (IKPA), budget, binoplast

\section{PENDAHULUAN}

Satuan militer dalam rangka melaksanakan tugas pokok perlu menjaga dan meningkatkan pembinaan kekuatan serta kesiapsiagaan satuansatuan operasional melalui latihan. Untuk mewujudkan peningkatan kemampuan dan kesiapsiagaan dapat ditempuh dengan jalan menyelenggarakan Binopslat. Agar kegiatan pembinaan operasi dan latihan dapat terselenggara dengan baik dan lancar sehingga tujuan dan sasaran yang diharapkan tercapai dibutuhkan dukungan anggaran yang memadai.

Perencanaan kebutuhan anggaran harus disusun dengan baik untuk mewujudkan akuntabilitas dan transparansi dalam penggunaan anggaran, sehingga dapat mendukung kegiatan Binopslat. Dengan perencanaan anggaran yang baik maka akan mewujudkan akuntabilitas dan transparansi peggunaan anggaran. Kementerian Keuangan selaku pemegang otoritas pengelolaan keuangan negara untuk mewujudkan akuntabilitas dan transparansi peggunaan anggaran 
negara, menerbitkan Indikator Kinerja Pelaksanaan Anggaran (IKPA).

IKPA merupakan alat ukur kualitas pelaksanaan anggaran Kementerian Negara/Lembaga yang dapat dipublikasikan untuk mendorong perubahan perilaku pengelolaan keuangan negara (Indonesia, 2018). IKPA adalah indikator untuk mengukur kualitas kinerja pelaksanaan anggaran belanja Kementerian Negara/Lembaga dari sisi kesesuaian terhadap perencanaan, efektivitas pelaksanaan kegiatan, efisiensi pelaksanaan kegiatan, dan kepatuhan terhadap peraturan. Menurut Rahmasari (2017) kepatuhan terhadap perundang-undangan dan total aset berpengaruh positif signifikan terhadap tingkat pengungkapan laporan keuangan.

Implementasi di lapangan dan berdasarkan pengalaman penugasan, masih terdapat beberapa permasalahan yang dihadapi dalam pelaksanaan pola penganggaran antara lain yaitu, belum dipatuhinya peraturan pengelolaan anggaran negara, pertanggungjawaban keuangan bertumpu pada akhir tahun anggaran, masih adanya pengembalian SPM, ketidak sesuaian antara perencanaan dengan pelaksanaan anggaran. Permasalahan diatas disebabkan pengelolaan manajamen keuangan yang tidak baik, sesuai pendapat Tim Dosen Administrasi Pendidikan, Universitas Pendidikan Indonesia (2009) manajemen keuangan meliputi kegiatan perencanaan, penggunaan, pencatatan data, pelaporan, dan pertanggung jawaban penggunaan dana sesuai dengan yang direncanakan, adapun tujuan manajemen keuangan adalah untuk mewujudkan tertibnya administrasi keuangan sehingga penggunaan keuangan dapat dipertanggungjawabkan sesuai dengan ketentuan yang berlaku. Beberapa permasalahan tersebut berimplikasi pada belum maksimalnya nilai IKPA Satker serta pelaksanaan rekonsiliasi antara SAIBA dengan SIMAK BMN belum optimal sehingga menjadi salah satu penyumbang belum tercapainya opini Wajar Tanpa Pengecualian atas Laporan Keuangan.

Tujuan dari penelitian yang akan dilaksanakan berdasarkan rumusan masalah yang diuraikan diatas adalah: 1). Mengetahui keterpengaruhan antara pertanggungjawaban anggaran terhadap manajemen keuangan Binopslat Sopsal. 2). Mengetahui keterpengaruhan antara efektivitas pelaksanaan kegiatan terhadap manajemen keuangan Binopslat Sopsal. 3). Mengetahui keterpengaruhan antara efisiensi pelaksanaan kegiatan terhadap manajemen keuangan Binopslat Sopsal. 4). Mengetahui keterpengaruhan antara penganggaran terhadap manajemen keuangan Binopslat Sopsal. 5). Mengetahui keterpengaruhan antara pertanggungjawaban, efektivitas, efisiensi dan anggaran secara bersama-sama terhadap manajemen keuangan Binopslat Sopsal.

\section{LANDASAN TEORI}

Untuk mendukung pelaksanaan penelitian, peneliti menggunakan beberapa teori untuk mendukung penelitian yang dilaksanakan. Beberapa teori yang digunakan adalah sebagai berikut:

\section{Teori Kepatuhan}

Teori kepatuhan telah diteliti pada ilmu-ilmu sosial khususnya di bidang psikologis dan sosiologi yang lebih menekankan pada pentingnya proses sosialisasi dalam mempengaruhi perilaku kepatuhan seorang individu. Kepatuhan merupakan suatu bentuk perilaku. Perilaku manusia berasal dari dorongan yang ada dalam diri manusia, sedang dorongan merupakan usaha untuk memenuhi kebutuhan yang ada dalam diri manusia (Purwanto, 1999). Seorang individu cenderung mematuhi hukum 
yang mereka anggap sesuai dan konsisten dengan norma-norma internal mereka. Komitmen normatif melalui moralitas personal berarti mematuhi hukum karena hukum tersebut dianggap sebagai suatu keharusan, sedangkan komitmen normatif melalui legitimasi berarti mematuhi peraturan karena otoritas penyusun hukum tersebut memiliki hak untuk mendikte perilaku. Berdasarkan definisi para ahli, kepatuhan merupakan perilaku seseorang yang berasal dari dalam dirinya untuk mentaati peraturan maupun ketentuan yang telah ditetapkan atas dasar kesadaran dari darinya maupun pengaruh lingkungan sekitarnya.

\section{Teori Manajemen Keuangan}

Membahas mengenai manajemen keuangan maka perlu untuk mengetahui tentang arti kata manajamen. Manajemen berasal dari bahasa latin manus yang berati tangan dan agere yang berarti melakukan, kata tersebut digabungkan menjadi kata kerja managere yang artinya menangani. Managere diterjemahkan ke dalam bahasa Inggris dalam bentuk kata kerja to manage, dengan kata benda management, dan manager untuk orang melakukan manajemen. Management diterjemahkan ke dalam bahasa Indonesia menjadi manajemen atau pengelolaan (Husaini, 2008). Manajemen keuangan merupakan penggabungan dari ilmu dan seni yang membahas, mengkaji dan menganalisis tentang bagaimana seorang manajer keuangan dengan mempergunakan seluruh sumber daya perusahaan untuk mencari dana, mengelola dana dan membagi dana dengan tujuan memberikan profit atau kemakmuran bagi para pemegang saham dan suistainability (keberlanjutan) usaha bagi perusahaan (Fahmi, 2013). Menurut Horne dan Wachowicz Jr., (2012) mengemukakan bahwa manajemen keuangan berkaitan dengan perolehan aset, pendanaan, dan manajemen aset dengan didasari beberapa tujuan umum.
Dari penjelasan teori tentang manajamen keuangan, maka dapat diintisarikan bahwa manajemen keuangan sebagai suatu pekerjaan yang mengatur penggunaan keuangan yang seefektiF, seefisien dan seproduktif mungkin untuk menghasilkan laba dan segala bentuk penggunaan keuangannya harus dapat dipertanggungjawabkan sesuai dengan ketentuan yang berlaku.

\section{Teori Anggaran}

Anggaran adalah rencana tertulis mengenai kegiatan suatu organisasi yang dinyatakan secara kuantitatif untuk jangka waktu tertentu dan umumnya dinyatakan dalam satuan uang (Nafarin, 2012). Sementara Sasongko dan Parulian (2015), berpendapat bahwa anggaran adalah rencana kegiatan yang akan dijalankan oleh manajemen dalam satu periode yang tertuang secara kuantitatif. Informasi yang dapat diperoleh dari anggaran diantaranya jumlah produk dan harga jualnya untuk tahun depan. Dari definisi yang disampaikan oleh para ahli tersebut, maka dapat disimpulkan bahwa anggaran adalah suatu rencana kerja yang disusun secara sistematis yang dinyatakan dalam satuan uang, barang atau jasa untuk waktu periode yang akan datang dalam suatu institusi atau organisasi tertentu. Dengan demikian, anggaran secara garis besar memenuhi besaran nominal dan juga esensi waktu kedepan. Mencermati hal tersebut, penyusunan anggaran harus dapat memprediksi tingkat aktivasi beserta kebutuhannya di masa mendatang, sehingga tujuan dari penyusunan anggaran adalah memenuhi kebutuhan di masa mendatang. Sasongko dan Parulian (2015) menyebutkan bahwa tujuan anggaran meliputi: a). Perencanaan, anggaran memberikan arahan bagi penyusunan tujuan dan kebijakan perusahaan. b). Koordinasi, anggaran dapat mempermudah koordinasi antar bagian-bagian di dalam perusahaan. c). Motivasi, anggaran membuat 
manajemen dapat menetapkan targettarget tertentu yang harus dicapai oleh perusahaan. d). Pengendalian, keberadaan anggaran di perusahaan memungkinkan manajemen untuk melakukan fungsi pengendalian atas aktivitas-aktivitas yang dilaksanakan dalam perusahaan.

Dengan menelaah dari pernyataan tentang tujuan anggaran tersebut, dapat disimpulkan bahwa tujuan disusunnya anggaran adalah sebagai pedoman bagi penyusunan tujuan dan kebijakan perusahaan, memudahkan koordinasi antar bagian-bagian di dalam perusahaan serta pengendalian atas aktivitas-aktivitas yang dilaksanakan dalam perusahaan.

\section{Teori Efektivitas}

Efektivitas adalah sebuah hubungan antara output dengan tujuan, semakin besar kontribusi (sumbangan) output terhadap pencapaian tujuan, maka semakin efektif organisasi, program atau kegiatan (Mahmudi, 2005). Menurut Abdurahmat (2003) menjelaskan tentang efektivas sebagai pemanfaatan sumber daya, sarana dan prasarana dalam jumlah tertentu yang secara sadar ditetapkan sebelumnya untuk menghasilkan sejumlah pekerjaan tepat pada waktunya. Merujuk pengertian tersebut dapat disimpulkan bahwa efektivitas berorientasi pada hasil yang dicapai.

\section{Teori Efisiensi}

Membahas efisiensi, tidak akan terlepas dari kata efektivitas hal ini karena efektivitas dan efisiensi adalah dua kata yang sering digunakan untuk menyampaikan pendapat terhadap suatu pencapaian. Efektivitas dan efisiensi adalah hal yang berbeda dan masingmasing memiliki pengertian sendiri. Efisiensi adalah perbandingan antara keluaran (output) dengan tujuan, hubungan antara keluaran dengan tujuan yang ingin dicapai, dan kemampuan untuk mengerjakan dengan benar (Suadi, 1999). Jika efektivitas berorientasi pada hasil, beda makna dengan efisien. Menurut Nopirin (2000) secara sederhana efisiensi dapat diartikan tidak adanya pemborosan. Dengan merujuk beberapa pendapat tersebut, dapat disimpulkan bahwa efisiensi sebagai penggunaan sumber daya secara minimum guna pencapaian hasil yang optimum. Efisiensi menganggap bahwa tujuan-tujuan yang benar telah ditentukan dan berusaha untuk mencari cara-cara yang paling baik untuk mencapai tujuan-tujuan tersebut. Efisiensi hanya dapat dievaluasi dengan penilaian-penilaian relatif, membandingkan antara masukan dan keluaran yang diterima.

\section{Teori Akuntabilitas}

Membahas masalah pengelolaan anggaran, tidak terlepas dari pentingnya penggunaan secara akuntabel. Istilah akuntabilitas berasal dari istilah dalam bahasa inggris accountability yang berarti pertanggunganjawab atau keadaan untuk dipertanggungjawabkan atau keadaan untuk diminta pertanggunganjawaban. Akuntabilitas sebagai bentuk kewajiban mempertanggungjawabkan keberhasilan atau kegagalan pelaksanaan misi organisasi dalam mencapai tujuan dan sasaran yang telah ditetapkan sebelumnya, melalui suatu media pertanggungjawaban yang dilaksanakan secara periodik (Mardiasmo, 2006). Selanjutnya Djalil (2014) menjelaskan bahwa akuntabilitas adalah sebuah konsep etika yang dekat dengan administrasi publik pemerintahan (lembaga eksekutif pemerintah, lembaga legislatif parlemen dan lembaga yudikatif) yang mempunyai beberapa arti antara lain, hal ini sering digunakan secara sinonim dengan konsep-konsep seperti yang dapat dipertanggungjawabkan (responbility), yang dapat dipertanyakan (answerbility), yang dapat dipersalahkan (blameworthiness) dan yang memunyai keterkaitan dengan harapan dapat 
menerangkan salah satu aspek dari administrasi publik/pemerintah. Sulistyani (2004) memberikan definisi yang lebih luas tentang akuntabilitas atau transparansi yaitu dua kata kunci dalam penyelenggaraan pemerintahan maupun penyelenggaraan perusahaan yang baik, dinyatakan juga bahwa dalam akuntabilitas terkandung kewajiban untuk menyajikan dan melaporkan segala kegiatan terutama dalam bidang administrasi keuangan kepada pihak yang lebih tinggi. Akuntabilitas dapat dilaksanakan dengan memberikan akses kepada semua pihak yang berkepentingan, bertanya atau menggugat pertanggungjawaban para pengambil keputusan dan pelaksana baik ditingkat program, daerah dan masyarakat.

Penelitian yang dilaksanakan oleh Rahmasari (2017) membuktikan bahwa SPI, kepatuhan terhadap perundangundangan dan total aset berpengaruh positif signifikan terhadap tingkat pengungkapan laporan keuangan. Variabel tindak lanjut rekomendasi hasil pemeriksaan tidak berpengaruh terhadap tingkat pengungkapan dan tingkat pengungkapan tidak berpengaruh terhadap opini audit BPK.

\section{Hipotesis}

Hipotesis dari penelitian adalah:

1. Terdapat pengaruh pertanggungjawaban anggaran terhadap manajemen keuangan Binopslat.

2. Terdapat pengaruh efektivitas pelaksanaan kegiatan terhadap manajemen keuangan Binopslat.

3. Terdapat pengaruh efisiensi pelaksanaan kegiatan terhadap manajemen keuangan Binopslat.

4. Terdapat pengaruh anggaran terhadap manajemen keuangan Binopslat.

5. Terdapat pengaruh pertanggungjawaban, efektivitas, efisiensi, anggaran secara simultan terhadap manajemen keuangan Binopslat.

\section{METODE PENELITIAN}

Metode yang digunakan dalam penelitian ini adalah metode campuran (mix methods) sequential explanatory, data kuantitatif diperoleh dari kuesioner yang dibagikan kepada responden. Hasilnya kemudian divalidasi dengan data kualitatif yang diperoleh dari hasil wawancara dengan narasumber untuk menjelaskan hasil analisa kuantitatif.

\section{Populasi dan Sampel}

Populasi dari penelitian yang dilaksanakan ini adalah staf Akun dan staf Perencanaan Sub Satker yang memiliki kriteria menangani masalah perencanaan, anggaran dan keuangan operasi dan latihan. Sampel yang dipilih dalam penelitian adalah keseluruhan populasi dikarenakan jumlah populasi hanya 37 orang staf.

\section{HASIL DAN PEMBAHASAN}

Penelitian dilaksanakan untuk membuktikan keterpengaruhan antara variabel bebas yaitu pertanggungjawaban $\left(\mathrm{X}_{1}\right)$, efektivitas $\left(\mathrm{X}_{2}\right)$, efisiensi $\left(\mathrm{X}_{3}\right)$ dan anggaran $\left(\mathrm{X}_{4}\right)$ terhadap variabel terikat manajemen keuangan (Y). Tahapan dalam penelitian sebagai berikut:

\section{Uji Instrumen Penelitian}

\section{Uji Validitas}

Hasil uji validitas terhadap instrumen penelitian membandingkan antara $r$ hitung dengan $r$ tabel, hasil dari uji ini adalah seluruh item peryataan $r$ hitung > 0,3246 ( $\mathrm{r}$ tabel) sehingga dapat disimpulkan bahwa seluruh pernyataan dalam kuesioner valid.

\section{Uji Reliabilitas}

Uji reliabilitas dilakukan dengan tujuan untuk mengetahui keandalan atau keakuratan suatu alat ukur dalam suatu prosedur pengukuran. Reliabilitas alat penilaian adalah ketepatan atau keajegan 
alat tersebut dalam menilai apa yang dinilainya. Artinya kapanpun penilaian tersebut digunakan akan memberikan hasil yang relatif sama (Sudjana, 2005). Hasil uji reliabilitas terhadap kuesioner penelitian apabila nilai Cronbach's Alpha $>$ 0,6 maka pernyataan dari setiap variabel reliabel. Hasil yang diperoleh seluruh peryataan dari setiap variabel memiliki nilai Cronbach's Alpha > 0,6 dapat disimpulkan bahwa seluruh pernyataan dalam kuesioner reliabel.

\section{Uji Asumsi Klasik}

\section{Uji Normalitas}

Pengujian normalitas data dilakukan untuk membuktikan apakah data yang akan dianlisis itu berdistribusi normal atau tidak. Langkah ini juga sebagai salah satu persyaratan regresi, hal ini merujuk pendapat yang menyatakan bahwa suatu data yang membentuk distribusi normal bila jumlah data diatas dan dibawah rata-rata adalah sama, demikian juga simpangan bakunya (Sugiyono, 2005). Untuk menjelaskan hasil uji apakah sebuah distribusi data bisa dikatakan normal atau tidak adalah dengan ketentuan kriteria apabila nilai Sig atau probabilitas $<0,05$ maka dapat disimpulkan distribusi data tidak normal, namun bila nilai Sig atau probabilitas > 0,05 akan dapat di katakan distribusi data normal (Santoso, 2006). Hasil uji normalitas dapat dilihat pada tabel 1 .

Tabel 1. Hasil Uji Normalitas

\begin{tabular}{l}
$\begin{array}{c}\text { One-Sample Kolmogorov-Smirnov } \\
\text { Test }\end{array}$ \\
\hline $\begin{array}{l}\text { Test Statistic }, 096 \\
\text { Asymp. Sig. (2- } \\
\text { tailed) }\end{array}$ \\
\hline a. Test distribution is Normal. \\
\hline b. Calculated from data. \\
\hline c. Lilliefors Significance Correction. \\
\hline $\begin{array}{l}\text { d. This is a lower bound of the true } \\
\text { significance. }\end{array}$ \\
\hline
\end{tabular}

Hasil uji normalitas dapat dilihat pada tebel 1, diperoleh nilai Asymp.Sig. hasil pengolahan data sebesar $0,200>$ 0,05. Dari hasil tersebut maka dapat disimpulkan seluruh item memiliki distribusi data normal.

\section{Uji Multikolineritas}

Dasar pengambilan keputusan dalam uji multikolinearitas adalah melihat nilai tolerance dan Variance Inflating Factor (VIF). Jika nilai tolerance $>0,10$ artinya tidak terjadi multikolinearitas dalam model regresi serta berlaku sebaliknya. Selanjutnya jika nilai VIF < 10,00 artinya tidak terjadi multikolinearitas dalam model regresi dan berlaku sebaliknya. Hasil pengujian yang dilaksanakan sebagai berikut: 
Tabel 2. Hasil Uji Multikolinearitas

\begin{tabular}{lcc}
\hline \multirow{2}{*}{\multicolumn{1}{c}{ Variabel }} & \multicolumn{2}{c}{ Collinearity Statistic } \\
\cline { 2 - 3 } & Tolerance & VIF \\
\hline Konstanta & & \\
Petanggung Jwb & 0.131 & 7.651 \\
Efektif & 0.110 & 9.057 \\
Efisien & 0.131 & 7.617 \\
Anggaran & 0.169 & 5.910 \\
\hline
\end{tabular}

a. Dependent Variabel: Manajemen_Keuangan

Uji multikolinearitas dilaksanakan dengan membandingkan antara nilai Tolerance variabel pertanggung jawaban, efektif, efisien dan anggaran > 0,10 dan nilai VIF pertanggung jawaban, efektif, efisien dan anggaran < 10,00. Berdasarkan hasil tabel diatas diperoleh nilai Tolerance pertanggungjawaban sebesar $0,131>0,10$; efektif sebesar
$0,110>0,10$; efisien sebesar $0,131>$ 0,10 ; anggaran sebesar $0,169>0,10$. Sedangkan nilai VIF dari pertanggungjawaban sebesar 7,651 < 10; efektif sebesar 9,057 < 10; efisien sebesar $7,617<10$ dan anggaran sebesar 5,910 < 10. Kesimpulan yang dapat diambil adalah tidak terjadi gejala multikolineritas antar variabel bebas.

\section{Pengaruh Pertanggungjawaban terhadap Manajemen Keuangan}

Tabel 3. Pengaruh Pertanggungjawaban terhadap Manajemen Keuangan

\begin{tabular}{lccc}
\hline \multicolumn{1}{c}{ Variabel } & Koefisien Regresi & t & Sig \\
\hline Konstanta & -7.783 & -1.10 & 0.275 \\
Pertanggung & 1.760 & 12.31 & 0.000 \\
jawaban & & & \\
\hline
\end{tabular}

a. Dependent Variable: Manajemen_Keuangan

Nilai koefisien determinasi sebesar 0,812 artinya konstribusi pertanggungjawaban terhadap manajemen keuangan sebesar $81,2 \%$, sedangkan sisanya sebesar 18,8\% disumbangkan faktor lain.

Nilai t tabel untuk df 32 sebesar $2,0369<\mathrm{t}$ hitung 12,31 . Sedangkan nilai Sig diperoleh sebesar $0,000<0,05$. Analisis dari perhitungan diperoleh hasil terdapat pengaruh signifikan antara pertanggungjawaban dengan manajemen keuangan. Persamaan regresi sederhana berdasarkan hasil dari tabel 3 diperoleh:

$$
Y=-7,783+1,760 X_{1}
$$

Dari persamaan tersebut dapat dijelaskan setiap kenaikan satu kali pertanggungjawaban, akan meningkatkan manajemen keuangan sebesar 1,760 kali. Koefisien bernilai positif, sehingga semakin baik pertanggungjawaban semakin meningkat manajemen keuangan. 


\section{Pengaruh Efektivitas terhadap Manajemen Keuangan}

Tabel 4. Pengaruh Efektivitas terhadap Manajemen Keuangan

\begin{tabular}{lccc}
\hline \multicolumn{1}{c}{ Variabel } & Koefisien Regresi & $\mathbf{t}$ & Sig \\
\hline Konstanta & -3.246 & -4.80 & 0.634 \\
Efktivitas & 1.979 & 12.13 & 0.000 \\
\hline
\end{tabular}

a. Dependent Variable: Manajemen_Keuangan

Perbandingan yang diperoleh antara $\mathrm{t}$ tabel 2,0369 < t hitung 12,13, sedangkan nilai Sig diperoleh sebesar $0,000<0,05$. Hasil penelitian menunjukkan bahwa terdapat pengaruh signifikan antara efektivitas dengan manajemen keuangan. Persamaan regresi sederhana berdasarkan hasil dari tabel 4 diperoleh:

$$
Y=-3,246+1,979 X_{2}
$$

Dari persamaan tersebut dapat dijelaskan setiap kenaikan satu kali efektivitas akan meningkatkan manajemen keuangan sebesar 1,979 kali. Koefisiennya bernilai positif, sehingga semakin baik efektivitas semakin meningkat manajemen keuangan.

Nilai koefisien determinasi sebesar 0,808 artinya kontribusi efektivtas sebesar $80,8 \%$ terhadap manajemen keuangan sebesar $80.8 \%$, sedangkan sisanya sebesar $19.2 \%$ disumbangkan faktor lain.

\section{Pengaruh Efisiensi terhadap Manajemen Keuangan}

Tabel 5. Pengaruh Efisnesi terhadap Manajaemen Keuangan

\begin{tabular}{lccc}
\hline \multicolumn{1}{c}{ Variabel } & Koefisien Regresi & $\mathbf{t}$ & Sig \\
\hline Konstanta & 4.397 & 0.715 & 0.480 \\
Efisiensi & 2.176 & 12.08 & 0.000 \\
\hline
\end{tabular}

a. Dependent Variable: Manajemen_Keuangan

Perbandingan yang diperoleh antara $\mathrm{t}$ tabel $2,369<\mathrm{t}$ hitung 12,08. Sedangkan nilai Sig diperoleh sebesar $0,000<0,05$. Hasil penelitian menunjukkan bahwa terdapat pengaruh signifikan antara efisiensi dengan manajemen keuangan. Persamaan regresi sederhana berdasarkan hasil dari tabel 5 diperoleh:

$$
\mathrm{Y}=4,397+2,176 \mathrm{X}_{3}
$$

Dari persamaan tersebut dapat dijelaskan setiap kenaikan satu kali efisiensi akan meningkatkan manajemen keuangan sebesar 2,176 kali. Koefisien bernilai positif, sehingga semakin baik efisiensi semakin meningkat manajemen keuangan.

Nilai koefisien determinasi sebesar 0,807 artinya kontribusi efisiensi kepada manajemen keuangan sebesar $80.7 \%$, sedangkan sisanya sebesar 19,.3\%. disumbangkan faktor lain. 


\section{Pengaruh Anggaran terhadap Manajemen Keuangan}

Tabel 6. Pengaruh Anggaran tarhadap Manajemen Keuangan

\begin{tabular}{cccc}
\hline Variabel & Koefisien Regresi & $\mathbf{t}$ & Sig \\
\hline Konstanta & 12.612 & 3.194 & 0.003 \\
Anggaran & 2.043 & 16.78 & 0.000 \\
\hline
\end{tabular}

a. Dependent Variable: Manajemen_Keuangan

Perbandingan yang diperoleh antara $\mathrm{t}$ tabel 2,0369 < t hitung 16,780. Sedangkan nilai Sig diperoleh sebesar $0,000<0,05$. Hasil penelitian menunjukkan bahwa terdapat pengaruh signifikan antara anggaran dengan manajemen keuangan. Persamaan regresi sederhana berdasarkan hasil dari tabel 6 diperoleh:

$$
\mathrm{Y}=12,612+2,043 \mathrm{X}_{4}
$$

Dari persamaan tersebut dapat dijelaskan setiap kenaikan satu skor anggaran akan meningkatkan manajemen keuangan sebesar 2,043 kali. Koefisien bernilai positif sehingga semakin baik anggaran semakin meningkat manajemen keuangan.

Nilai koefisien determinasi sebesar 0,889 artinya kontribusu anggaran terhadap variabel manajemen keuangan sebesar 88,9\%, sedangkan

\section{KESIMPULAN DAN SARAN}

\section{Kesimpulan}

Hasil penelitian dapat disimpulkan sebagai berikut: 1). Berdasarkan hasil penelitian menunjukkan bahwa penyusunan pertanggungjawaban keuangan yang patuh pada peraturan berpengaruh terhadap kelancaran penyaluran dukungan anggaran Binopslat Sopsal. Hasil tersebut dibuktikan bahwa penyusunan dokumen pertanggungjawaban keuangan yang benar, lengkap dan tepat waktu akan mendukung kelancaran penyaluran dukungan anggaran Binopslat, sehingga mewujudkan manajemen keuangan yang sisanya sebesar $11,1 \%$ disumbangkan faktor lain..

\section{Pengaruh Pertanggungjawaban, Efektivitas, Efisiensi dan Anggaran terhadap Manajemen Keuangan}

Nilai $\mathrm{F}$ hitung sebesar 95,718 > F tabel 2,67, sedangkan nilai sig 0,000 < 0,05 dari kedua uji tersebut dapat disimpulkan ada pengaruh signifikan antara pertanggungjawaban, efektivitas, efisiensi dan anggaran terhadap manajemen keuangan.

Nilai koefisien determinasi ( $\mathrm{R}$ Square) sebesar 0,923 artinya kontribusi variabel pertanggungjawaban, efektivitas, efisiensi dan anggaran sebesar 92,3\% terhadap variabel manajemen keuangan, sedangkan sisanya sebesar 7,7\% disumbangkan faktor lain.

baik. 2). Berdasarkan hasil penelitian menunjukkan bahwa efektivitas pelaksanaan kegiatan berpengaruh terhadap penyaluran dukungan anggaran Binopslat Sopsal. Hasil tersebut dibuktikan bahwa output pelaksanaan kegiatan mematuhi IKPA akan mendukung kelancaran penyaluran dukungan anggaran Binopslat, sehingga mewujudkan manajemen keuangan yang baik. 3). Berdasarkan hasil penelitian menunjukkan bahwa efisiensi pelaksanaan kegiatan berpengaruh terhadap penyaluran dukungan anggaran Binopslat Sopsal. Hasil tersebut 
dibuktikan bahwa semakin efisien pelaksanaan kegiatan dengan meminimalisir kesalahan dan mematuhi peraturan yang berlaku akan mendukung kelancaran penyaluran dukungan anggaran Binopslat sehingga mewujudkan manajemen keuangan yang baik. 4). Berdasarkan hasil penelitian menunjukkan bahwa anggaran berpengaruh terhadap penyaluran dukungan anggaran Binopslat Sopsal. Hasil tersebut dibuktikan bahwa penyusunan perencanaan anggaran yang baik akan mewujudkan kesesuaian antara perencanaan dan pelaksanaan kegiatan yang berpengaruh terhadap kelancaran penyaluran dukungan anggaran Binopslat, sehingga mewujudkan manajemen keuangan yang baik. 5). Berdasarkan hasil penelitian menunjukkan bahwa penyusunan pertanggungjawaban, efektivitas pelaksanaan kegiatan, efisiensi pelaksanaan kegiatan dan penganggaran berpengaruh signifikan baik parsial maupun secara bersama-sama terhadap penyaluran dukungan anggaran Binopslat Sopsal.

\section{Saran}

1). Satker menyampaikan data kontrak secara tepat waktu ke KPPN maksimal 5 hari kerja setelah kontrak pengadaan anggaran Binopslat ditandatangani, Bendahara Pengeluaran meminimalisir dispensasi terhadap Surat Perintah Membayar (SPM) yang diajukan ke KPPN dengan menepati batas waktu pengajuan 2 hari kerja setelah Surat Permintaan Pembayaran (SPP) ditandatangani dan menepati pertanggungjawaban penggunaan Uang Persediaan (UP) 30 hari kerja setelah UP diterima dari KPPN serta menyampaikan laporan pertanggujawaban ke KPPN maksimal tanggal 10 pada bulan berikutnya. 2). Meminimalisir kesalahan pembuatan SPM yang menyebabkan terjadinya pengembalian SPM oleh KPPN, menepati rencana penarikan dana sesuai dengan rencana penarikan kas yang diajukan ke KPPN. 3). Menyusun rencana kegiatan dan menyelenggarakan kegiatan Bionpslat sesuai dengan Rencana Kerja dan Anggaran yang telah disetujui dan ditetapkan, serta tidak menunda pengajuan pertanggungjawaban keuangannya untuk menghindari realisasi anggaran yang bertumpu pada akhir tahun anggaran, menepati periodesasi penyelesaian tagihan dari pihak ketiga ke KPPN sesuai jangka waktu tujuh belas hari kerja sesuai dengan ketentuan dan meminimalisir terjadinya retur SP2D yang berakibat adanya utang negara kepada pihak ketiga serta terlambatnya manfaat yang diterima. 4). Menyusun dan melaksanakan Rencana Kerja Anggaran dengan baik untuk meminimalisir terjadinya revisi DIPA pada tahun anggaran berjalan. Pabandya Minku Sopsal dan Akun Kupus Diskual meminimalisir terjadinya perbedaan antara perencanaan penarikan dana terhadap realisasi setiap bulannya sehingga memperkecil deviasi halaman III DIPA. 5). Satker mematuhi seluruh indikator dalam IKPA dengan baik dalam pengelolaan anggaran Binoslat Sopsal yang meliputi kesesuaian dengan perencanaan, meningkatkan efektivitas pelaksanaan kegiatan, meningkatkan efisiensi pelaksanaan kegiatan dan meningkatkan kepatuhan terhadap peraturan yang berlaku untuk mewujudkan manajemen keuangan yang baik sehingga penyaluran dukungan anggaran kegiatan dapat tersalurkan tepat waktu.

\section{DAFTAR PUSTAKA}

Abdurahmat. (2003). $\begin{gathered}\text { Penegrtian } \\ \text { Efektivitas. Jakarta: PT Rineka } \\ \text { Cipta. }\end{gathered}$
Djalil, R. (2014). Akuntabilitas Keuangan Daerah. Jakarta: Rmbooks. 
Fahmi, I. (2013). Analisis Laporan Keuangan). Bandung: Alfabeta.

Husaini, U. (2008). Manajemen, Teori Praktik dan Riset Pendidikan. Jakarta: Bumi Aksara.

Indonesia, K. K. (2018). Monitoring dan Evaluasi Pelaksanaan Anggaran Belanja Kementerian Negara/Lembaga. Jakarta: Kementerian Keuangan Republik Indonesia.

James Horne dan John Wachowicz Jr. (2012). Prinsip-Prinsip Manajemen Keuangan. Jakarta: Salemba Empat.

Mahmudi. (2005). Manajemen Kinerja Sektor Publik. Yogyakarta: BPFE.

Mardiasmo. (2006). Perpajakan, Edisi Revisi. Yogyakarta: Andi Offset.

Mulyana, D. (2018). Metodologi Penelitian Kualitatif Paradigma Baru Ilmu Komunikasi dan Ilmu Sosial Lainnya. Bandung: PT Remaja Rosdakarya.

Nafarin, M. (2012). Penganggaran Perusahaan. Jakarta: Salemba Empat.

Nopirin. (2000). Pengantar Ilmu Ekonomi Makro dan Mikro. Yogyakarta: BPFE.

Purwanto, H. (1999). Pengantar Perilaku Manusia. Jakarta: EGC.

Rahmasari, D. (2017). Pengaruh Sistem Pengendalian Internal, Kepatuhan
Terhadap Perundang-Undangan, Tindak Lanjut Rekomendasi Hasil Pemeriksaan dan Total Aset Terhadap Opini Audit Dengan Tingkat Pengungkapan Pada Catatan Atas Laporan Keuangan Kementerian/Lembaga. Lampung: Dewi Rahmasari.

Santoso. (2005). Jakarta: PT Elex Media Komputindo.

Santoso. (2006). Menggunakan SPSS Untuk Statistik Non Parametrik. Jakarta: PT Elex Media Komputindo.

Sasongko dan Parulian. (2015). Jakarta: Salemba Empat.

Sasongko dan Parulian. (2015). Anggaran. Jakarta: Salemba Empat.

Suadi, A. (1999). Sistem Pengendalian Manajemen. Yogyakarta: BPFE.

Sudjana. (2005). Metode Statistika Edisi ke 6. Bandung: Tarsito.

Sugiyono. (2005). Metode Penelitian Kuantitatif, Kualitatif, $\quad R \& D$. Bandung: Alfabeta.

Sulistyani, A. T. (2004). Kemitraan dan Model-Model Pemberdayaan. Yogyakarta: Graha Ilmu.

Tim Dosen Administrasi Pendidikan, Universitas Pendidikan Indonesia. (2009). Manajemen Pendidikan. Bandung: Alfabet. 